\title{
ПРАВОПРОСВІТНИЦТВО ЯК СКЛАДОВА ЧАСТИНА ФУНКЦІОНАЛЬНИХ ОБОВ'ЯЗКІВ ФАХІВЦІВ СИСТЕМИ БЕЗОПЛАТНОЇ ПРАВОВОЇ ДОПОМОГИ - ПРАКТИЧНІ АСПЕКТИ РЕАЛІЗАЦІї
}

\section{1. Вступ}

Сьогодні в українській державі обізнаність населення про свої права, способи їх реалізації, захисту та поновлення, є досить низькою, а це безпосередньо впливає на можливість становлення правової держави та формування інститутів громадянського суспільства, які $\epsilon$ невід'ємними елементами євроінтеграційної перспективи України. Саме тому безпосередньо держава повинна бути першочерговим зацікавленим суб'єктом підвищення правової обізнаності, правової культури та правової свідомості населення, створюючи для цього максимально сприятливі умови. Метою дослідження є вивчення та аналіз інституційної структури підрозділів системи безоплатної правової допомоги в Україні, що здійснюють право просвітницьку функцію, дослідження їхніх завдань та функцій, а також механізму адміністрування.

1 Аспірант кафедри конституційного, адміністративного та фінансового права, Західноукраїнський національний університет, vovakarui@gmail.com, https://orcid. org/0000-0003-0634-988X. 


\section{2. Здійснення адміністрування правопросвітництва на рівні держави та регіону}

Формування правосвідомості та правової культури зі сторони держави повинно пронизувати усі вікові та професійні групи, зокрема, розпочинаючись у закладах молодшої та середньої освіти. Свого часу функцію правопросвітництва виконували підрозділи територіальних управлінь Міністерства юстиції, проте, з реформуванням останніх дана функція була скасована, а підрозділи ліквідовано.

3 моменту свого створення у 2013 році функцію правопросвітництва віднесено до основних завдань системи безоплатної правової допомоги, на ряду із безпосередній наданням первинної та вторинної правової допомоги. Останнє уточнення вкрай важливе, адже побутує думка про другорядність функцій правопросвітництва, ігноруючи важливість цього аспекту роботи, що в практиці діяльності системи безоплатної правової допомоги категорично не знаходить своєї підтримки, що підтверджується функціонуванням та постійним розвитком підрозділів, що виконують дану частину роботи.

Підвищення правової свідомості, культури та освіченості населення $\epsilon$ одним з основних завдань системи безоплатної правової допомоги. Це декларується у підпункті 1 пункту 7 «Положення про центри з надання безоплатної вторинної правової допомоги», затвердженого наказом Міністерства юстиції України від 02 липня 2012 року № 967/5².

Станом на сьогодні у системі безоплатної правової допомоги функціонує сформована вертикаль підрозділів, що виконують функції правопросвітництва, формування якої завершилось відносно нещодавно створенням управління правопросвітництва та вивчення правових потреб населення Координаційного центру з надання правової допомоги. Даний структурний підрозділ очолює струк-

2 Про затвердження Положення про центри з надання безоплатної вторинної правової допомоги: наказ Міністерства юстиції України від 02 липня 2012 року № 967/5. URL: https://zakon.rada.gov.ua/laws/show/z1091-12 (дата звернення 08.11.2021). 
турну вертикаль правопросвітницького напряму системи безоплатної правової допомоги та координує цей напрям роботи, проте, не являючись окремою юридичною особою та не містячи функцій безпосереднього керівництва відділами інших структур (маються на увазі регіональні та місцеві центри з надання безоплатної вторинної правової допомоги).

Власне, вищезгадані регіональні та місцеві центри з надання безоплатної вторинної правової допомоги, а точніше їх підрозділи продовжують правопросвітницьку вертикаль повноважень. На рівні регіону координує та безпосередньо здійснює правопросвітницьку роботу відділ правопросвітництва та комунікацій Регіонального центру, який також був реформований у 2019 році, а до цього моменту мав назву відділу комунікації та забезпечення доступу до публічної інформації, хоча в посадових обов'язках фахівців і тоді містилось правопросвітництво. Навіть виходячи з найменування відділів робимо висновок та знову констатуємо особливу, системну увагу до правпросвітницького напряму роботи.

Основними завданнями відділу комунікацій та правопросвітництва в частині правопросвітництва $є$ :

1) надання актуальної інформації мешканцям територіальних громад щодо реалізації права на безоплатну правову допомогу;

2) координація та спрямування роботи відділів правопросвітництва та надання безоплатної правової допомоги місцевих центрів з надання безоплатної вторинної правової допомоги, що підпорядковані регіональному центру, в частині інформаційного супроводження діяльності системи надання безоплатної правової допомоги,організації правопросвітницьких інформаційних кампаній та правопросвітницьких заходівна території відповідного регіону³.

3 Про затвердження Типових положень про структурні підрозділи регіональних центрів з надання безоплатної вторинної правової допомоги (крім регіональних центрів з надання безоплатної вторинної правової допомоги у Донецькій та Запорізькій, Луганській та Харківській областях): Наказ Координаційного центру з надання правової допомоги від 26 березня 2019 року № 36. URL: https:// www.legalaid.gov.ua/publikatsiyi-ta-resursy/chynnezakonodavstvo/organizatsijnorozporyadchi-dokumenty (дата звернення 07.11.2021). 
Звісно, даний перелік завдань підрозділу не є вичерпним, у статті наведено ті завдання, які після проведеного аналізу можна віднести безпосередньо до правопросвітницького напрямку роботи. Якщо аналізувати глибше кожен з наведених пунктів, то робимо висновок про те, що перше завдання передбачає цілий ряд підзавдань, це, зокрема і організація право просвітницьких заходів, і безпосереднє їх проведення, це залучення партнерських організацій до заходів, це залучення різних цільових аудиторій. Одночасно з цим формулювання завдання «...щодо реалізації права на безоплатну правову допомогу» можна трактувати як комплексне, адже право на правову допомогу може стосуватися будь-якої сфери правовідносин, з цього робимо висновок про універсальність тематики правопросвітництва, який обмежується лише кваліфікацією спікера заходу (будь то фахівець системи чи залучений партнер).

\section{3. Організація правопросвітницької роботи у місцевих центрах з надання БВПД}

У другому пункті завдань відділу Регіонального центру згадується відділ правопросвітництва та надання безоплатної правової допомоги місцевих центрів з надання безоплатної вторинної правової допомоги, яких у підпорядкуванні Регіональних центрів може бути різна кількість, в залежності від територіальної та демографічної специфіки регіону, на який поширюється його юрисдикція (до прикладу на території Тернопільської області три місцевих центри, а на території Дніпропетровської - п'ять).

Відділ правопросвітництва та надання безоплатної правової допомоги місцевого центру з надання безоплатної вторинної правової допомоги є самостійним структурним підрозділом місцевого центру з надання безоплатної вторинної правової допомоги.

Основними завданнями Відділу є:

1) правопросвітництво у територіальних громадах;

2) надання безоплатної первинної правової допомоги;

3) забезпечення доступу до безоплатної вторинної правової допомоги;

4) надання безоплатної вторинної правової допомоги; 
5) сприяння формуванню та розвитку на відповідній території мережі суб'єктів надання безоплатної первинної правової допомоги;

6) забезпечення доступу до електронних сервісів Міністерства юстиції України

Вище наведено повний перелік завдань відділу, при цьому, описуючи їх, я свідомо навів саме повний перелік, не змінюючи послідовності, яка встановлення установчим документом відділу - Положенням, аби підкреслити важливість завдання правопросвітництва, яке в переліку вказане першим пунктом.

Для реалізації вищезазначених завдань відділ наділений рядом повноважень, проаналізувавши які, нижче наводжу перелік тих, які спрямовані на реалізацію право просвітницької функції.

Зокрема, Відділ відповідно до покладених на нього завдань:

1) розповсюджує інформацію у сфері захисту прав, свобод і законних інтересів громадян, надання безоплатної правової допомоги, у тому числі в установах виконання покарань. Установи відбування покарань виділені окремим пунктом у зв'язку з тим, що особи, засуджені до покарання у вигляді позбавлення волі, тримання в дисциплінарному батальйоні військовослужбовців або обмеження волі наділені Законом України «Про безоплатну правову допомогу» правом на всі види безоплатної правової допомоги 5 .

2) проводить тематичні семінари, лекції, зокрема у навчальних закладах, закладах позашкільної освіти, в закладах післядипломної освіти, навчально-виховних закладах для дітей-сиріт та дітей, позбавлених батьківського піклування; для визначених категорій громадян, зокрема пенсіонерів, осіб з інвалідні-

4 Про затвердження Типових положень про структурні підрозділи місцевих центрів з надання безоплатної вторинної правової допомоги: Наказ Координаційного центру з надання правової допомоги від 09 червня 2017 року № 149. URL: https://zakon.rada.gov.ua/laws/show/v0149419-17\#n163 (дата звернення 10.11.2021).

5 Про безоплатну правову допомогу: Закон України від 09 липня 2011 р. № 3460 / Верховна рада України. URL: https://zakon.rada.gov.ua/laws/show/3460-17 (дата звернення 10.11.2021). 
стю, учасників антитерористичної операції, молоді, громадських активістів, вчителів та педагогічних працівників, медичних працівників, інших вразливих суспільних груп з метою підвищення правової свідомості, культури та освіченості населення, запобігання злочинності;в даному підпункті перелічений ряд цільових аудиторій проведення правопросвітницьких заходів, проте, він також не $є$ вичерпним, а правопросвітницька діяльність системи охоплює значно більше категорій.

3) надає правову інформацію, консультацію і роз'яснення з правових питань, зокрема роз'яснює порядок звернення до відповідних міжнародних судових установ чи відповідних міжнародних організацій, членом або учасником яких $\epsilon$ Україна;даний пункт не $\epsilon$ безпосередньо правопросвітницьким, але має пряме відношення до виконання цього завдання,

4) забезпечує інформаційне супроводження діяльності місцевого центру та інформування щодо права на безоплатну правову допомогу шляхом: поширення на сторінках місцевого центру, зокрема у соціальних мережах, та у засобах масової інформації інформаційно-роз'яснювальних матеріалів у сфері захисту прав, свобод і законних інтересів громадян, зокрема у межах тематичних тижнів права системи надання безоплатної правової допомоги, всеукраїнських правопросвітницьких кампаній.

\section{4. Поняття та ознаки правопросвітницької кампанії}

Якщо детальніше описувати вищезгадані правопросвітницькі кампанії, то система безоплатної правової допомоги визначає їх як визначені у часі, триваючі певний проміжок часу (місяць, квартал, півріччя) правопросвітницькі заходи. які мають визначену мету, цільову аудиторію та прогнозовані результати. В практиці роботи системи ці критерії визначаються Координаційним центром як органом, який спрямовує та здійснює загальну координацію правопросвітницької діяльності всієї системи. Детальніше проаналізувавши цей термін робимо висновок, що правопросвітницька кампанія повинна мати: визначену мету, що формується з урахуванням правових потреб населення (як правило, кампанії приурочуються 
до тих чи інших знакових дат); прогнозований результат та можливість здійснити аналіз їх кількісних та якісних показників (основним кількісним показником прийнято вважати кількість учасників заходів, тоді як якість оцінюється на підставі аналізу зворотнього зв'язку з учасниками); підтримку громади, її готовність долучитись до реалізації кампанії, або надати ресурсну підтримку (часто до організації заходу залучаються партнери, які можуть бути в ролі спікера чи інфлюенсера, який поширюватиме інформацію про захід); готовність та бажання потенційної аудиторії кампанії сприймати інформацію (даним критерієм і обґрунтовується приурочення кампаній до певних знакових дат, тобто визначення тематики, як на момент проведення кампанії $€$ актуальної для тих чи інших цільових груп).

Правопросвітницькі кампанії проводяться різними шляхами, зокрема основними з них $є$ : поширенні інформації про право громадян, іноземців чи осіб без громадянства на безоплатну правову допомогу та інші базові права людини; роз'яснення законодавства; поширення інформації та роз'яснень по зміни, що вносяться до законодавства; ознайомлення з суттю та змістом реформ, що проводяться в державі; формування вмінь та навичок у складенні документів правового характеру (цей пункт стосується проведення заходів практичного спрямування як то практикуми чи тренінги).

\section{5. Правопросвітницький напрям діяльності бюро правової допомоги}

Завершує вертикаль правопросвітницьких підрозділів системи безоплатної правової допомоги ще один відділ місцевих центрів, який розділений територіально від основного місцезнаходження центрів, саме тому і виділений як окрема складова вертикалі - бюро правової допомоги.

Бюро правової допомоги також є самостійним відділом місцевого центру з надання безоплатної вторинної правової допомоги. Основними завданнями бюро $є$ :

1) правопросвітництво у територіальних громадах;

2) надання безоплатної первинної правової допомоги; 
3) забезпечення доступу до безоплатної вторинної правової допомоги;

4) надання безоплатної вторинної правової допомоги (крім захисту);

5) забезпечення доступу до електронних сервісів Міністерства юстиції.

Аналогічно відділу правопросвітництва та надання безоплатної правової допомоги місцевого центру з надання безоплатної вторинної правової допомоги бюро правової допомоги як самостійний підрозділ містить ряд завдань, серед яких знову ж таки першим визначено правопросвітництво. Звернімо увагу, що в типових установчих документах двох з чотирьох підрозділів місцевого центру основним завданням визначено саме правопросвітництво, а це знову ж таки свідчить про системний підхід та пріоритезацію саме цього напрямку роботи в адмініструванні системи безоплатної правової допомоги.

Говорячи про повноваження бюро правової допомоги в частині правопросвітництва, то дублювати їх немає потреби, адже вони повністю збігаються з повноваженнями відділу правопросвітництва та надання безоплатної правової допомоги місцевого центру з надання безоплатної вторинної правової допомоги, які детально описані у статті раніше, а вищезгаданий відділ здійснює спрямування та загальну координацію в межах юрисдикції місцевого центру.

На етапі існування повноцінної сформованої системи безоплатної правової допомоги, українській державі належить забезпечити рівень поінформованості населення про можливість скористатись таким правом. Станом на завершення 2019 року про функціонування системи безоплатної правової допомоги знали 24\% населення держави. Планом діяльності Уряду було передбачено до 2021 року збільшити рівень поінформованості жителів України про можливість скористатись своїм правом на безоплатну правову допомогу до 50\%. Станом на сьогодні цей показник становить понад 54\%. Цей показник $є$ безпосередній віддзеркаленням правопросвітницької та комунікативної діяльності системи в комплексі, частково його можна застосовувати для аналізу правової обізнаності жителів нашої держави, адже знання про право на отримання безоплатної 
правової допомогти є одним з індикаторів підвищення рівня правової обізнаності населення.

Центри безоплатної правової допомоги проводять правопросвітницьку роботу з метою підвищення рівня правової свідомості, обізнаності, культури та вдосконалення системи правової освіти населення. Набуття громадянами необхідного рівня правових знань, формування у них поваги до права, подолання правового нігілізму, особливо серед вразливих верств населення - саме таку мету декларує система безоплатної правової допомоги.

3 погляду забезпечення реальності права на отримання кваліфікованої юридичної допомоги особливого значення набуває політика держави в галузі правової свідомості. На сьогодні більшість громадян має погане уявлення про свої права і свободи, тому не завжди усвідомлено ними користується. Задовольнити цю потребу може довідкова правова література, попит на яку поступово зростає, а також спеціальні радіо - і телепередачі, які роз'яснювали 6 громадянам основи права, ознайомлювали б, зокрема, з їхніми правами та обов'язками. Належне висвітлення у засобах масової інформації - запорука успіху будь-якого державного проекту, пов'язаного з доступністю для кожної особи кваліфікованої юридичної допомоги. Зрозуміти, чи може громадянин претендувати на отримання безоплатної юридичної допомоги та куди йому потрібно звернутися, досить складно. За відсутності належного інформування це право людини може залишитись нереалізованим, а політика держави в цій галузі - неефективною (популістською) 6.

\section{6. Висновки}

Цілком слушно погодитись з Д.В. Гончаром, який зазначає про такі інструменти підвищення рівня правової поінформованості населення як довідкова література та висвітлення прав людини у засобах мсової інформації. Це комунікаційно-просвітницькі аспекти роботи системи безоплатної правової допомоги, які також мають місце

6 Гончар Д.В. Механізм гарантування права на отримання кваліфікованої юридичної допомоги: національні тенденції та зарубіжний досвід: монографія. Кам'янець-Подільський, 2019, 199 с. 
у інституційній структурі системи, а тому ми бачимо переспективу подальших наукових досліджень у напрямку підвищення рівня правової обізнаності системою безоплатної правової допомоги, а також іншими органами юстиції та освітніми закладами.

Підсумовуючи, можна зробити висновки про те, що формування вертикалі правопросвітницьких підрозділів системи безоплатної правової допомоги станом на сьогодні завершено, одночасно з цим важливим $\epsilon$ те, що як нормативно, так і практично реалізується принцип пріоритетності правопросвітницької функції системи безоплатної правової допомоги в Україні.

\section{Література}

Гончар Д.В. Механізм гарантування права на отримання кваліфікованої юридичної допомоги: національні тенденції та зарубіжний досвід: монографія. Кам'янець-Подільський, 2019, 199 с.

Про безоплатну правову допомогу: Закон України від 09 липня 2011 р. № 3460 / Верховна рада України. URL: https://zakon.rada. gov.ua/laws/show/3460-17 (дата звернення 10.11.2021).

Про затвердження Типових положень про структурні підрозділи місцевих центрів з надання безоплатної вторинної правової допомоги: Наказ Координаційного центру з надання правової допомоги від 09 червня 2017 року № 149. URL: https://zakon.rada.gov. ua/laws/show/v0149419-17\#n163 (дата звернення 10.11.2021).

Про затвердження Типових положень про структурні підрозділи регіональних центрів з надання безоплатної вторинної правової допомоги (крім регіональних центрів з надання безоплатної вторинної правової допомоги у Донецькій та Запорізькій, Луганській та Харківській областях): Наказ Координаційного центру з надання правової допомоги від 26 березня 2019 року № 36. URL: https://www.legalaid.gov.ua/publikatsiyi-ta-resursy/ chynnezakonodavstvo/organizatsijno-rozporyadchi-dokumenty (дата звернення 07.11.2021).

Про затвердження Положення про центри з надання безоплатної вторинної правової допомоги: наказ Міністерства юстиції України 
від 02 липня 2012 року № 967/5. URL: https://zakon.rada.gov.ua/ laws/show/z1091-12 (дата звернення 08.11.2021).

\section{References}

Honchar D.V. (2019) Mekhanizm harantuvannia prava na otrymannia kvalifikovanoi yurydychnoi dopomohy: natsionalni tendentsii ta zarubizhnyi dosvid: monohrafiia [The mechanism of guaranteeing the right to receive qualified legal aid: national trends and foreign experience: a monograph]. Kamianets-Podilskyi [in Ukrainian].

Verkhovna rada Ukrainy (2011) Pro bezoplatnu pravovu dopomohu: Zakon Ukrainy vid 09 lypnia 2011 r. № 3460 [On free legal aid: Law of Ukraine of July 9, 2011 № 3460]. Retrieved from: https://zakon. rada.gov.ua/laws/show/v0149419-17\#n163.

Koordynatsiinyi tsentr z nadannia pravovoi dopomohy (2017) Pro zatverdzhennia Typovykh polozhen pro strukturni pidrozdily mistsevykh tsentriv z nadannia bezoplatnoi vtorynnoi pravovoi dopomohy: Nakaz Koordynatsiinoho tsentru z nadannia pravovoi dopomohy vid 09 chervnia 2017 roku № 149 [On approval of the Standard Regulations on structural subdivisions of local centers for free secondary legal aid: Order of the Coordination Center for Legal Aid of June 9, 2017 № 149]. Retrieved from: https://zakon.rada.gov. ua/laws/show/v0149419-17\#n163.

Koordynatsiinyi tsentr z nadannia pravovoi dopomohy (2019) Pro zatverdzhennia Typovykh polozhen pro strukturni pidrozdily rehionalnykh tsentriv z nadannia bezoplatnoi vtorynnoi pravovoi dopomohy (krim rehionalnykh tsentriv z nadannia bezoplatnoi vtorynnoi pravovoi dopomohy u Donetskii ta Zaporizkii, Luhanskii ta Kharkivskii oblastiakh): Nakaz Koordynatsiinoho tsentru z nadannia pravovoi dopomohy vid 26 bereznia 2019 roku № 36 [On approval of the Standard Regulations on structural subdivisions of regional centers for free secondary legal aid (except for regional centers for free secondary legal aid in Donetsk and Zaporizhia, Luhansk and Kharkiv regions): Order of the Coordination Center for Legal Aid of March 26, 2019 № 36]. Retrieved from: https://www.legalaid.gov. 
ua/publikatsiyi-ta-resursy/chynne-zakonodavstvo/organizatsijnorozporyadchi-dokumenty/.

Ministerstvo yustytsii Ukrainy (2017) Pro zatverdzhennia Polozhennia pro tsentry z nadannia bezoplatnoi vtorynnoi pravovoi dopomohy: nakaz Ministerstva yustytsii Ukrainy vid 02 Iypnia 2012 roku № $967 / 5$ [On approval of the Regulations on centers for free secondary legal aid: order of the Ministry of Justice of Ukraine of July 2, 2012 № 967/5]. Retrieved from: https://zakon.rada.gov.ua/laws/show/ z1091-12.

\section{Анотація}

У статті описано адміністративну структуру підрозділів системи безоплатної правової допомоги в Україні, що здійснюють функцію правопросвітництва. Детально розглянуто та проаналізовано завдання, обов'язки та повноваження правопросвітницьких підрозділів на кожному з інституційних рівнів системи безоплатної правової допомоги, а також наведено територіальний розподіл юрисдикції таких підрозділів. Автор проаналізував зв язок , ступінь підпорядкування та загальної координації дій між підрозділами різних рівнів структури.

У публікації також визначено та обґрунтовано важливий нормативно закріплений та фактично реалізований пріоритет, що надається правопросвітницькій діяльності у системі безоплатної правової допомоги України. У публікації описано досвід реалізації правопросвітницької діяльності іншими структурними підрозділами Міністерства юстиції України, а також наведено статистичні дані щодо обізнаності жителів країни про право на отримання безоплатної правової допомоги як частини формування правової свідомості населення. Детально розглянуто поняття правопросвітницьких кампаній, що проводяться системою безоплатної правової допомоги $з$ виокремленням їх базових ознак та способів реалізації.

Ключові слова: правопросвітницькі заходи. громади, правова свідомість, правова культура, правова обізнаність, завдання, адміністрування, правопросвітницька кампанія

Volodymyr Karyy - Postgraduate Student at the Department of Constitutional, Administrative and Financial Law, West Ukrainian National University, vovakarui@gmail.com, https://orcid.org/0000-0003-0634-988X 


\section{LEGAL EDUCATION AS AN INTEGRAL PART OF THE FUNCTIONAL RESPONSIBILITIES OF SPECIALISTS OF THE FREE LEGAL AID SYSTEM - PRACTICAL ASPECTS OF IMPLEMENTATION}

\section{Summary}

The article describes the administrative structure of the units of the free legal aid system in Ukraine, which perform the function of legal education. The tasks, responsibilities and powers of legal education units at each of the institutional levels of the free legal aid system are considered and analyzed in detail, as well as the territorial division of jurisdiction of such units. The author analyzed the relationship, the degree of subordination and general coordination of actions between units of different levels of the structure.

The publication also identifies and substantiates an important normatively enshrined and actually implemented priority given to legal education activities in the system of free legal aid in Ukraine. The publication describes the experience of legal education activities by other structural units of the Ministry of Justice of Ukraine, as well as statistics on the awareness of residents of the country about the right to receive free legal aid as part of the formation of legal awareness. The concept of legal education campaigns conducted by the system of free legal aid with the separation of their basic features and methods of implementation is considered in detail.

Keywords: legal education activities. communities, legal consciousness, legal culture, legal awareness, tasks, administration, legal education campaign 